ISSN : 2581-1320 (Print) ISSN : 2581-2572 (Online)

Homepage: http://ejurnal.ikippgribojonegoro.ac.id/index.php/J-ABDIPAMAS

\title{
PELATIHAN PEMBUATAN PELEMBUT DAN PEWANGI PAKAIAN BAGI IBU-IBU PKK BINA MUFAKAT DI DESA BAYEUN KECAMATAN BIREM BAYEUN KABUPATEN ACEH TIMUR
}

\author{
Nursamsu $^{1}$, Allif Syahputra Bania ${ }^{2}$ \\ ${ }^{1}$ Universitas Samudra. Email: samsu bio@unsam.ac.id \\ 2Universitas Samudra. Email: allifbania@unsam.ac.id
}

\begin{abstract}
Member of PKK Bina Mufakat, Bayeun Village, Birem Bayeun District, East Aceh Regency have held community service activity by conducting training in making clothes softener and perfume products. The method of implementation consists of three stages, namely preparation, explanation / implementation and creation. The training participants were PKK women of Bina Mufakat consisting of 20 people. The results obtained from the preparation stage, namely the service activities stated that member of PKK Bina Mufakat welcomed the service so that it determined the service activity schedule, the second stage of the service team's explanation explained the benefits of softener and perfume products used as business opportunities as additional household income while the third stage of manufacture was there very satisfying success in products made with the community service team with Member of PKK Bina Mufakat.
\end{abstract}

Keywords: Training, Softener, Fragrance, Clothing

\begin{abstract}
ABSTRAK
Anggota PKK Bina Mufakat Desa Bayeun Kecamatan Birem Bayeun Kabupaten Aceh Timur telah melaksanakan kegiatan pengabdian kepada masyarakat dengan melakukan pelatihan membuat produk pelembut dan pewangi pakaian. Metode pelaksanaan terdiri dari tiga tahap yaitu persiapan, penjelasan/pelaksanaan dan pembuatan. Peserta pelatihan tersebut adalah angota PKK Bina Mufakat yang terdiri dari 20 orang. Hasil yang didapatkan dari tahap persiapan yaitu pada kegiatan pengabdian menyatakan bahwa angota PKK menyambut dengan baik sehingga menentukan jadwal kegiatan pengabdian, tahap kedua penjelasan tim pengabdian menjelaskan manfaat dari produk pelembut dan pewangi pakaian dijadikan peluang usaha sebagai pendapatan tambahan rumah tangga sedangkan tahap ketiga pembuatan yaitu terdapat keberhasilan sangat memuaskan pada produk yang dibuat bersama tim pengabdian dengan Ibu PKK Bina Mufakat.
\end{abstract}

Kata Kunci: Pelatihan, Pelembut, Pewangi, Pakaian

\section{PENDAHULUAN}

\section{Analisis Situasi}

Pelembut pakaian merupakan salah satu bahan berupa cairan yang terjadi dalam proses tahapan awal dan akhir membuat pakaian yang dicuci menjadi lembut dan wangi (Laksono, 2018). Menurut pendapat Handoko (2009) menyatakan bahwa softener dengan pH netral dapat membuat kondisi pencucian mempermudah mencakup terhadap permukaan kain. Pewangi ini sangat lembut serta dapat meninggalkan aroma yang tahan 
lama pada serat kain. Bahan utama pelembut dan pewangi pakaian adalah surfaktan yang sering digunakan oleh industri (Scheibel, 2004).

Softener selain untuk melembutkan pakaian juga sebagai pengharum pakaian. Aroma parfum softener dapat tahan lama melekat pada pakaian. adanya Fixative yang berfungsi sebagai mengikat dan pengawet parfum itu sendiri kedalam serat kain. Pelembut dan pewangi pakaian ini juga disebut dengan softener merupakan bahan yang berupa cairan yang kental, berfungsi sebagai pelembut dan pewangi pakaian. Sebanyak 73 persen responden yang mendukung dan ikut berpartisipasi dalam Gerakan Sekali Bilas yang dihimbau dalam tayangan iklan salah satu produk pelembut dan pewangi pakaian sekali bilas yang bertujuan untuk penghematan air negara (Felicia, 2011).

Berdasarkan pendapat diatas bahwa produk pelembut dan pewangi pakian dapat dijadikan suatu peluang usaha bagi masyarakat. Apalagi pada saat sekarang ini, dunia sedang menghadapi pandemi covid-19 yang telah menyebar di berbagai Negara, termasuk Indonesia. Bahkan sudah menyebar di Propinsi Aceh. Penyebaran covid-19 ini berdampak negatif bagi perekonomian masyarakat, sehingga banyak kita dengar para ibu rumah tangga mengeluh dikarenakan pendapatan suami untuk kehidupan sehari - hari berkurang bahkan hampir tidak ada. Permasalahan ini merupakan salah satu tugas PKK untuk membantu meringatkan beban para anggotanya melalui pelatihan yang dapat meningkatkan kreatifitas dan keterampilan ibu PKK Bina Mufakat Desa Bayeun Kecamatan Birem Bayeun Kabupaten Aceh Tamiang sehingga memicu semangat berwirausaha guna membantu perekonomian rumah tangga.

Sebagai wujud pengabdian kami terhadap permasalahan diatas, kami dari tim pengabdian Universitas Samudra akan membantu PKK Bina Mufakat Desa Bayeun melalui pelatihan pembuatan pewangi pakaian kepada para anggota nya dengan tujuan untuk memberikan ilmu dan teknologi tepat guna, dapat menambah pendapatan ibu PKK Bina Mufakat Desa Bayeun dengan cara memberikan pelatihan dan praktek pembuatan pelembut dan pewangi pakaian dan juga memberikan solusi peluang usaha bagi masyarakat, khususnya bagi para ibu rumah tangga.

Pemilihan Desa tersebut didasari dari hasil survey kami pada tanggal 20 April 2020 yang bertemu langsung dengan Ketua Ibu PKK Bina Mufakat Desa Bayeun beliau berkata bahwa belum ada satu pun pengabdian yang dilakukan di Desa tersebut oleh instansi manapun baik dari lembaga sosial masyarakat maupun dari pemerintah setempat, yang memberikan pelatihan bagi ibu PKK Bina Mufakat.

Berdasarkan analisis situasi diatas mengenai permasalahan yang dihadapi oleh masyarakat, khususnya para ibu rumah tangga yang mempunyai permasalahan pada masa pandemik covid-19 yang menghadapi permasalahan perekonomian yang berkurangnya untuk pendapatan sehari -hari, kami sebagai tim membuat pengabdian yang berjudul" Pelatihan Keterampilan Pembuatan Pelembut Dan Pewangi Pakaian Sebagai Peluang Usaha Bagi Ibu PKK Bina Mufakat".

\section{Permasalahan Mitra}

Persoalan yang dihadapi terhadap permasalahan dalam pelaksanaan kegiatan pengabdian yaitu (a) Belum adanya perhatian pemerintah untuk membuat pelatihan 
kepada Ibu PKK Bina Mufakat Desa Bayeun; (b) Belum adanya instansi lain yang melaksanakan pengabdian kepada Ibu PKK Bina Mufakat Desa Bayeun; (c) Belum adanya pembinaan kewiusahaan kepada Ibu PKK Bina Mufakat Desa Bayeun.

\section{Justifikasi Solusi Atas Permasalahan Mitra}

Dari hasil telaah permasalahan yang dihadapi, maka solusi yang dapat diusulkan untuk menyelesaiakan permasalahan yang ada adalah sebagai berikut: (a) Pelatihan pembuatan pewangi pakaian bagi Ibu PKK Bina Mufakat Desa Bayeun Kecamatan Birem Bayeun Kabupaten Aceh Timur; (b) Peningkatan pemberdayaan Ibu PKK Bina Mufakat Desa Bayeun dalam proses berwirausaha dan membuat pewangi pakaian.

\section{METODE PELAKSANAAN}

Tim pengabdian kepada masyarakat melaksakan kegiatan pengabdian dengan Ibu PKK Bina Mufakat Di Desa Bayeun Kecamatan Birem Bayeun Kabupaten Aceh Timur yang dilaksanakan pada bulan Juli sampai Agustus 2020. Pelaksanaan kegiatan pengabdian menggunakan alat yaitu kompor gas, tabung gas, panci, gelas ukur, pengaduk, ember, tong air dan botol. Sedangkan bahan yang digunakan dalam pembuatan pelembut dan pewangi pakaian adalah bahan pelicin, stabilizer, pengawet, pengikat parfume dan parfume.

Selanjutnya dilakukan tahap - tahapan dalam pelaksanaan kegiatan pengabdian dengan Ibu PKK Bina Mufakat Di Desa Bayeun Kecamatan Birem Bayeun Kabupaten Aceh Timur dilakukan melalui 5 (lima) tahapan yang meliputi (1) Survey; (2) Pelatihan keterampilan Pembuatan Sabun; (3) Monotoring dan Evaluasi. Metode pelatihan ini dimaksudkan untuk memberikan gambaran dan dorongan kepada Ibu PKK Bina Mufakat sebagai usaha rumah tangga atau usaha kelompok desa (Nuris, dkk., 2020).

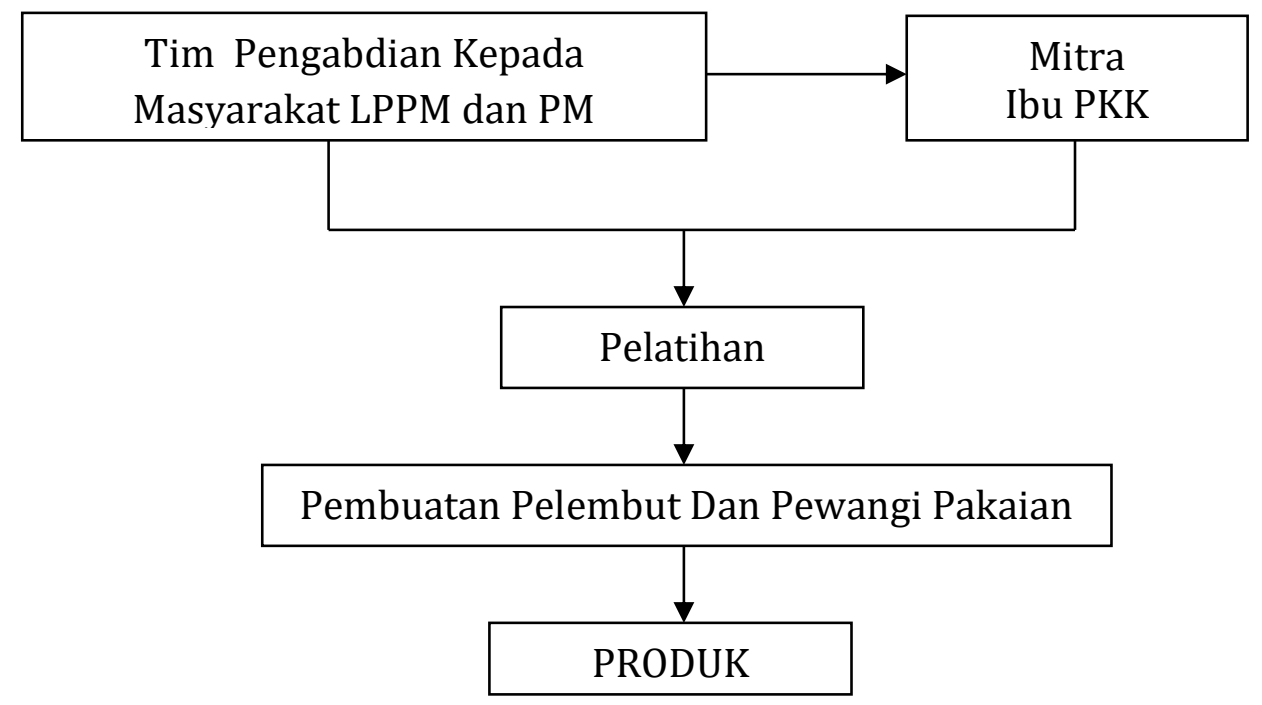

Gambar 1. Rancangan Pelatihan Pengabdian Kepada Masyarakat 


\section{HASIL DAN PEMBAHASAN}

Hasil kegiatan pengabdian yang dilaksanakan oleh tim pengabdian terdiri beberapa tahap sesuai dengan metode pelaksanaan dapat dijelaskan dibawah ini.

\section{Tahap Survey}

Sebelum pelaksanaan kegiatan pengabdian, maka tim pengabdian melakukan survey awal ke lokasi kegiatan pengabdian. Hal ini membuat kesepakatan kerjasama tim pengabdian dengan Ibu PKK Bina Mufakat sebagai mitra. Kedatangan kami membuat dampak positif bagi mitra, terjadi perbincangan yang membuat termotivasi kami untuk memberikan pelatihan kepada Ibu PKK Bina Mufakat, disebabkan bahwa belum adanya instansi manapun melakukan kegiatan pelatihan kepada Ibu PKK Bina Mufakat. Kesepakatan kerjasama ini membuat penetuan jadwal dalam pelaksanaan kegiatan pengabdian kepada Ibu PKK Bina Mufakat.

\section{Tahap Pelatihan}

Ada beberapa proses yang dilaksanakan oleh tim pengabdian untuk menjelaskan pembuatan pelembut dan pewangi pakaian sebagai berikut.

a. Persiapan dimana tim pengabdian memperkenalkan alat dan bahan dalam membuat pelembut dan pewangi pakaian. Tim pengabdian juga menjelaskan bahwa pelatihan ini memberikan pengetahuan bagi Ibu PKK Bina Mufakat bagaimana membuat peluang usaha Ibu rumah tangga atau sebagai usaha kelompok Ibu PKK.

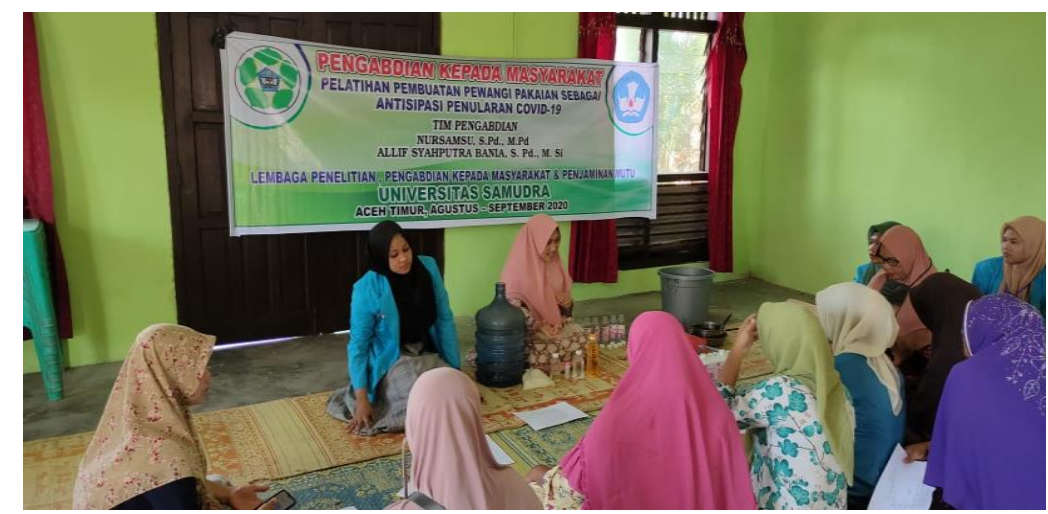

Gambar 2. Penjelasan Tim Pengabdian

b. Proses pembuatan pelembut dan pewangi pakaian adalah (1) Rebuskan 2 liter air panas; (2) Sudah air mendidih masukkan bahan pelicin dan diaduk sampai tidak gumpalan lagi; (3) Masukkan 25 liter air bersih kedalam tong air; (4) Masukkan bahan stabiliter; (5) Masukkan bahan pengawet; (6) Masukkan bahan pengikat parfume; (7) Masukkan pelicin yang sudah larut dalam air sebagai pelembut pakaian; (8) Masukkan parfume berlahan - lahan. Setelah bahan tercampur maka diaduk sampai rata. selanjutnya masukkan pelembut dan pewangi pakaian kedalam botol yang telah disediakan. 


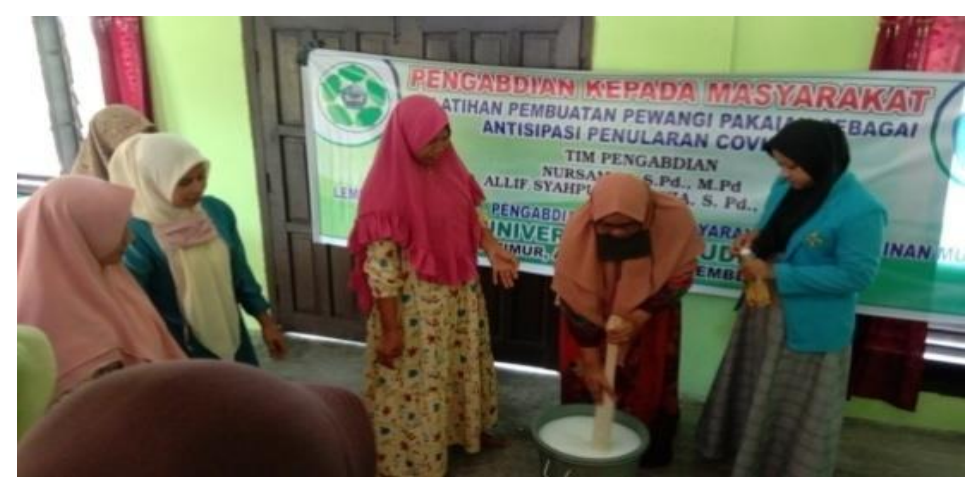

Gambar 3. Pembuatan Pelembut dan Pewangi Pakaian

c. Proses pengemasan produk yang dilaksanakan oleh tim pengabdian dengan Ibu PKK Bina Mufakat di Desa Bayeun Kecamatan Birem Bayeun Kabupaten Aceh Timur.

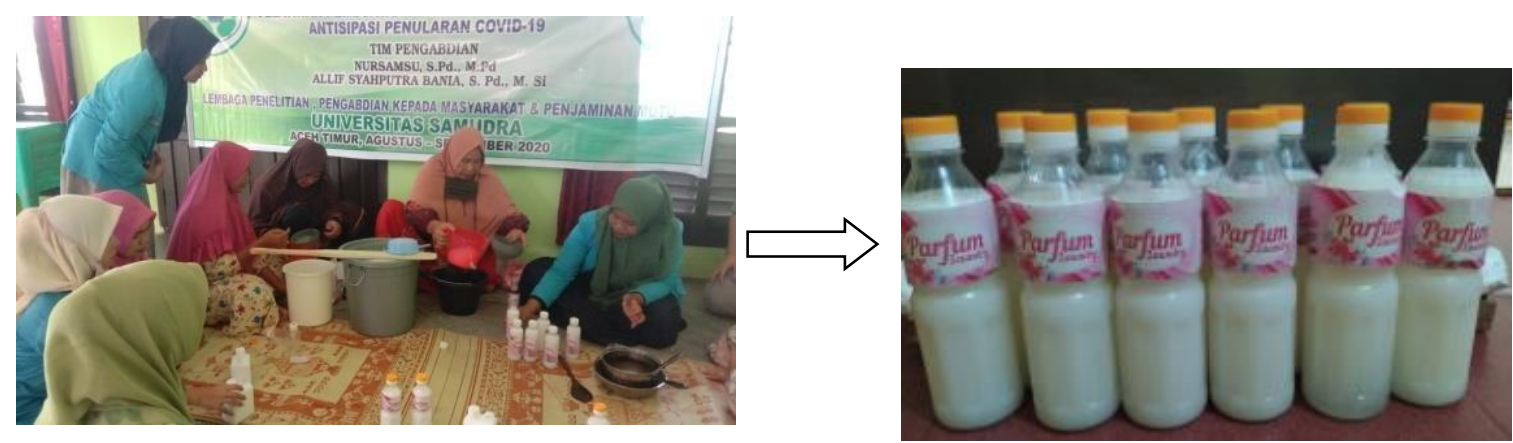

Gambar 4. Pengemasan dan Produk

\section{Tahap Monotoring dan Evaluasi}

Pada tahap ini tim pengabdiian melakukan menyebaran angket kepuasan kepada Ibu PKK Bina Mufakat. Penyebaran angket ini untuk mengetahui kepuasan Ibu PKK Bina Mufakat dari hasil pelatihan pembuatan pelembut dan pewangi pakaian. Adapun angket yang dibuat menggunakan skala Likert dengan pilihan jawaban 1-4 (1= sangat tidak puas; 2 = tidak puas puas; 3 = puas; $4=$ sangat puas). Angket ini diberikan kepada 20 orang jumlah peserta kegiatan. Untuk mengetahui hasil dari penyebaran angket dapat di lihat pada tabel 1.

Tabel 1. Tingkat Kepuasan Ibu PKK Bina Mufakat Di Desa Bayeun Kecamatan Birem Bayeun Kabupaten Aceh Timur

\begin{tabular}{|c|c|c|c|c|}
\hline No. & Uraian Pernyataan & Jumlah & Rata-rata & Keterangan \\
\hline \multirow[t]{2}{*}{1.} & Bagaiamana menurut pendapat Ibu & & & \\
\hline & $\begin{array}{l}\text { Program Pengabdian kepada Masyarakat } \\
\text { (PKM) }\end{array}$ & 18 & $90 \%$ & $\begin{array}{l}\text { Sangat } \\
\text { Puas }\end{array}$ \\
\hline 2 & $\begin{array}{l}\text { Materi proses pembuatan pelembut dan pewangi } \\
\text { pakaian pelaksanaan program PKM memberikan } \\
\text { pengetahuan }\end{array}$ & 15 & $75 \%$ & Puas \\
\hline 3 & $\begin{array}{l}\text { Pelaksanaan program memberikan keterampilan } \\
\text { bagi Ibu - Ibu dalam peluang usaha }\end{array}$ & 14 & $70 \%$ & Puas \\
\hline 4 & $\begin{array}{l}\text { Personil/anggota yang terlibat dalam kegiatan } \\
\text { pengabdian masyarakat memberikan pelayanan }\end{array}$ & 17 & $85 \%$ & $\begin{array}{l}\text { Sangat } \\
\text { Puas }\end{array}$ \\
\hline
\end{tabular}




\begin{tabular}{llccc}
\hline No. & \multicolumn{1}{c}{ Uraian Pernyataan } & Jumlah & Rata-rata & Keterangan \\
\hline $\begin{array}{l}\text { sesuai dengan kebutuhan saya } \\
\text { Setelah pelaksanaan program PKM akan dilanjutkan } \\
\text { lagi untuk membuat produk ini }\end{array}$ & 13 & $65 \%$ & Puas \\
\hline Jumlah Rata - Rata & 77 & $77,0 \%$ & Puas \\
\hline
\end{tabular}

Berdasarkan hasil data yang terdapat pada tabel 1 mengenai penyebaran angket kepuasan, maka hasil yang didapatkan adalah 77,0\%. Hasil dari kegiatan pengabdian dengan melaksanakan pelatihan pembuatan pelembut dan pewangi pakaian dinyatakan puas bagi Ibu PKK Bina Mufakat, maka dapat disimpulkan bahwa kegiatan pengabdian memberikan dampak positif.

Hasil dari monotoring tim pengabdian kepada Ibu PKK Bina Mufakat juga memberikan kontribusi yang bermanfaat bagi mereka sebagai peluang usaha kelompok Ibu PKK Bina Mufakat. Mereka sudah mempunyai pendapatan tambahan bagi kelompok dari hasil penjualan produk pelembut dan pewangi pakaian

\section{SIMPULAN}

Tahap survey yang dilaksanakan oleh tim pengabdian memberikan bahwa Ibu PKK menyambut dengan baik sehingga menyetujui dan menentukan jadwal kegiatan pengabdian. Selanjutnya tahap pelatihan yang dilakukan oleh tim pengabdian dalam proses penjelasan pembuatan produk pelembut dan pewangi pakaian memberikan dampak positif bagi Ibu PKK Bina Mufakat, karena memberikan pengetahuan dalam membuat produk. Sedangkan tahap monotoring dan evaluasi memberikan kepuasan kepada Ibu PKK Bina Mufakat dapat dimanfaatkan sebagai peluang usaha.

\section{UCAPAN TERIMA KASIH}

Tim pengabdian mengucapkan terima kasih kepada Lembaga Penelitian, Pengabdian Kepada Masyarakat \& Penjaminan Mutu Universitas Samudra yang telah memberikan dana DIPA dari hibah pengabdian kepada masyarakat pada Tahun 2020, sehingga dapat diselesaikan tepat pada waktunya.

\section{DAFTAR RUJUKAN}

Felicia. (2011). Sikap ibu rumah tangga Surabaya terhadap isi pesan iklan molto ultra sekali bilas di televisi. Surabaya:FISIP Universitas Pembangunan Nasional "Veteran".

Handoko, H.B. (2009). Laundry Chemicals. Medan : Universitas Sumatera Utara.

Laksono, E. W, SYL Isana, Marfuatun, L \& Yuanita, D. (2018). Pelatihan Pembuatan Pelembut Cucian yang Ramah Lingkungan, J. Pengabdian Masyarakat MIPA dan Pendidikan MIPA, 2(1), 38 - 42.

Nuris, D.M., Primasa Minerva Nagari, P.M \& Nuraini, U. (2020). Pelatihan Pembuatan Bahan Ajar Dan Media Pembelajaran Berbasis Tik Bagi Guru Akuntansi. J-ABDIPAMAS (Jurnal Pengabdian Kepada Masyarakat). 4(1), 75 - 82. 
Scheibel, J.J. (2004). The Evolution of Anionic Surfactants Technology to Meet the Requirements of the Laundry Deterjent Industry, J. Surfactants. Deterg. 7(4), 319 328. 
28 J-Abdipamas, Vol. 4, No. 2 Oktober, 2020 